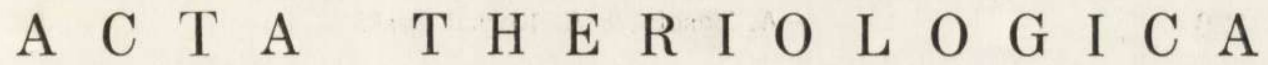 \\ VOL. XVII, 11: 119-134. \\ BIAŁOWIEŻA \\ May, 1972
}

BISONIANA L.

Alicja LASOT A \& Andrzej KOS S A KOW S K I

\section{Microscopic Structure of the Bone during Ontogenesis of the European Bison}

\author{
[With 4 Tables \& 5 Figs]
}

The bones of the European bison deriving from the individuals in the age between 0 and 20 years were examined. Eight periods in the bison life showing differences in the bone microscopic structure were distinguished. The differences arise from the fact that the processes of bone remodelling persist throughout the bison life. They are manifested in two ways: (a) Resorption of old structures with simultaneous appearrance of new osteons growing in the space available due to the resorption. These new osteons show large haversian canals with a small number of concentrical lamellae surrounding the channel. (b) Maturation of individuals associated with the increased number of lamellae and narrowed lumen of haversian canals. The intensity of these two parallel processes varies with age, giving in effect cyclic changes in the bone structure. The cyclic character of changes is best manifested by the analysis of the mean diameter of haversian canals. This feature varies in a 9 years cycle characterized by alternating increase and reduction of the mean channel diameter. The periosteous zone of the bone shows certain differences in the process of development.

\section{INTRODUCTION}

Since almost seventy years the investigations have been carried out in order to establish differences in microscopic structure of human and animal bones, as well as to find out species-specific features and relationship between the picture of polished bone sections and the age of an individual. The results reported by various authors were not univocal. Some authors observed significant differences in the microscopic appearance of human and animal bones (B e u m e r, 1914; S chranz, 1933; Simonin, 1955; M ueller, 1953; Thomps on \& Ballou, 1956; $\mathrm{Ramsch}$ \& Z erndt, 1963; Kossakowski, 1964), while others 
disputed their existence ( $\mathrm{G}$ i e s e, 1909; W a d a, 1909; Gr a s s, 1916). Only very few authors studied the changes of the bone microscopic structure during ontogenesis of the man and animals ( $\mathrm{Lacroix}, 1951$, as well as Barhazard, Dervieux, Lebrun \& Muller, cited after Simonin, 1947). The age-dependent variability in man has been also confirmed by the studies of one of us ( $\mathrm{K}$ o s s a k ow s ki, 1964).

On the basis of the discussed literature an attempt was undertaken to investigate the changes in the bone microscopic structure during ontogenesis of a selected animal species.

The obtaining of properly selected and representative bone material from large mammals encounters considerable difficulties. The commonly employed practical methods of determination of individual age of dead wild animals permit of a significant tolerance, which would affect the results of investigations. On the other hand, the authors intended to study a mammal species living in natural (not laboratory) conditions. The studies of $\mathrm{Gebhard}$ (cited after Giese, 1909) demonstrated that external factors may exert an effect on the functionality and thus on the structure of the bone as well. For this reason the European bison was selected as the object of the investigations. This species has remained under strict protection for many years and the pedigree-books are available, hence in every case an accurate determination of the age and sex of the animal is possible.

\section{MATERIAL AND METHOD}

The bones of 36 European bisons, Bison bonasus (L in na e us, 1758), belonging to the collection of the Research Centre of the Bison Anatomy at the Department of Animal Anatomy, Warsaw Agric. University, constituted the material for the investigations. The material included 19 males and 16 females in the age from birth until 20 years of age, as well as one male foetus. The cause of death of each animal was checked in order to exclude bisons which died in the course of chronic diseases affecting the bone system. The presented material includes the animals which were killed during mutual fights or by mechanical injury, eventually put asleep for scientific purposes.

From the skeleton of all individuals transverse segments of the left tibia were taken in the middle of the diaphysis at the lateral side. The segments were used to prepare polished bone sections subsequently analysed in the polarized light in a NU microscope. The morphological description of the development and remodelling of the bone was prepared on the basis of appearance of whole sections. Three zones differing in the size of structural elements could be distinguished on bone sections. For this reason the measurements were carried out separately in: (a) the periosteous zone, (b) the central zone, and (c) the perimedullary zone (or bone-marrow adjoining zone). Each of these zones was characterized in respect of the following parameters: (1) diameter of haversian canals, (2) number of these channels per $1 \mathrm{~mm}^{2}$, (3) smaller diameter of bone cavities (lacunae). 
In each zone of the polished bone section 150 measurements of diameters of haversian canals and of bone cavities were carried out. The number of haversian canals was estimated in 15 microscopic fields of vision. The magnification of 180 times was used, and the field of vision corresponded to $1.7 \mathrm{~mm}^{2}$. The arithmetic mean was calculated from the obtained results, and then for the whole section the weighted mean was computed.

Moreover, the total area of sectioned haversian canals was determined with a planimeter on microphotographs. These data were related to the area of a photographed segment of the bone section. The obtained indices characterized the relationship between the areas occupied by particular structural elements of the bone at different age.

The analysis of changes of the studied parameters with the age of animals was carried out on the basis of smoothed curves. These curves were obtained by interpolation of points corresponding to arithmetic means of determinations of a given parameter in each individual. The curves for males and females were analyzed separately in order to avoid obscuring of the picture by eventual differences between sexes.

\section{RESULTS}

\section{General Morphological Observations}

On the basis of observed changes in microscopic picture of the bone the studied fragment of ontogenesis can be divided into several periods:

1. The foetal period (Fig. 1.1) is characterized by a picture typical for intensive growth and reconstruction of the bone. Not all architectonic elements of the bone are already present, and rather scarce primary osteons show blurred outlines. For this reason the picture of foetal bone cannot be compared with that from older individuals. Primary bone trabeculae separated by irregular fissures of variable shape and size surround in rows the bone-marrow cavity. Around some, not numerous fissures there appear 2-3 concentrical lamellae containing osteocytes. They represent the most primitive forms of osteons.

2. The most intensive development of the bone occurs during the first year of life (Fig. 1.2). Irregular fissures of large diameter - characteristic for the foetal period - became separated by lamellae and hence transformed into haversian canals. The number of osteons composed of a few lamellae increases. They are arranged in rows parallel to the bonemarrow cavity. The osteons are often oval in shape and their outlines are not clear. The diameter of haversian canals is small.

3. In the period of the second and third year of life (Fig. 1.3) the osteons produce surrounding lamellae from the external side, their outlines become more distinct. The arrangement in rows still prevails. The mean diameter of haversian canals increases. Rather numerous Volkmann's canals and appearing new osteons can be observed in this period. 

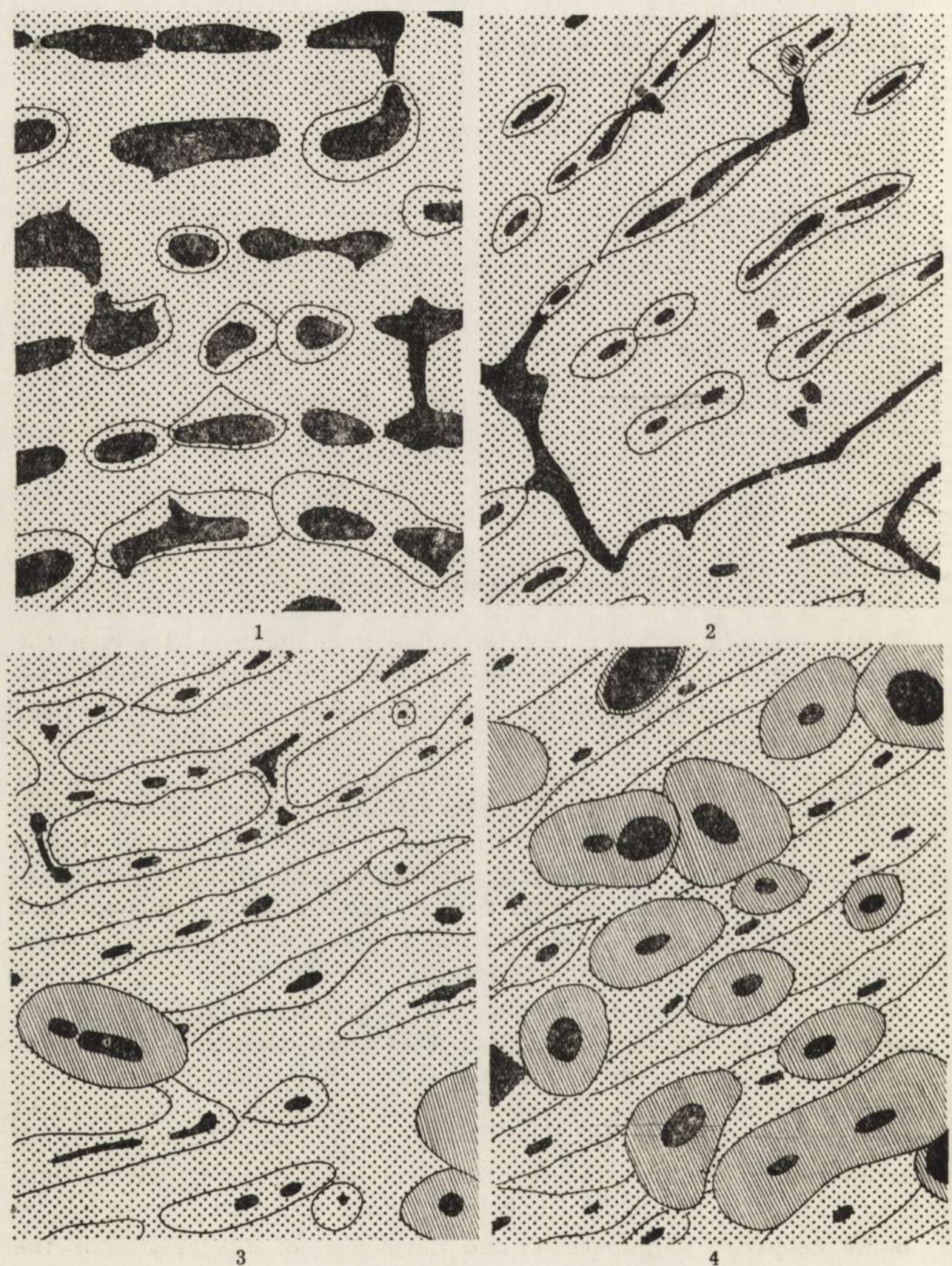

Fig. 1. Scheme of changes in the microscopic picture of the European bison bone in relation to age.

1. Foetus, 2. First year of life, 3. Individual in the age of 3 years, 4. Individual in the age of 6 years, 5. Individual in the age of 8 years, 6 . Individual in the age of 11 years, 7. Individual in the age of 15 years, 8. Individual in the age of 18 years. 

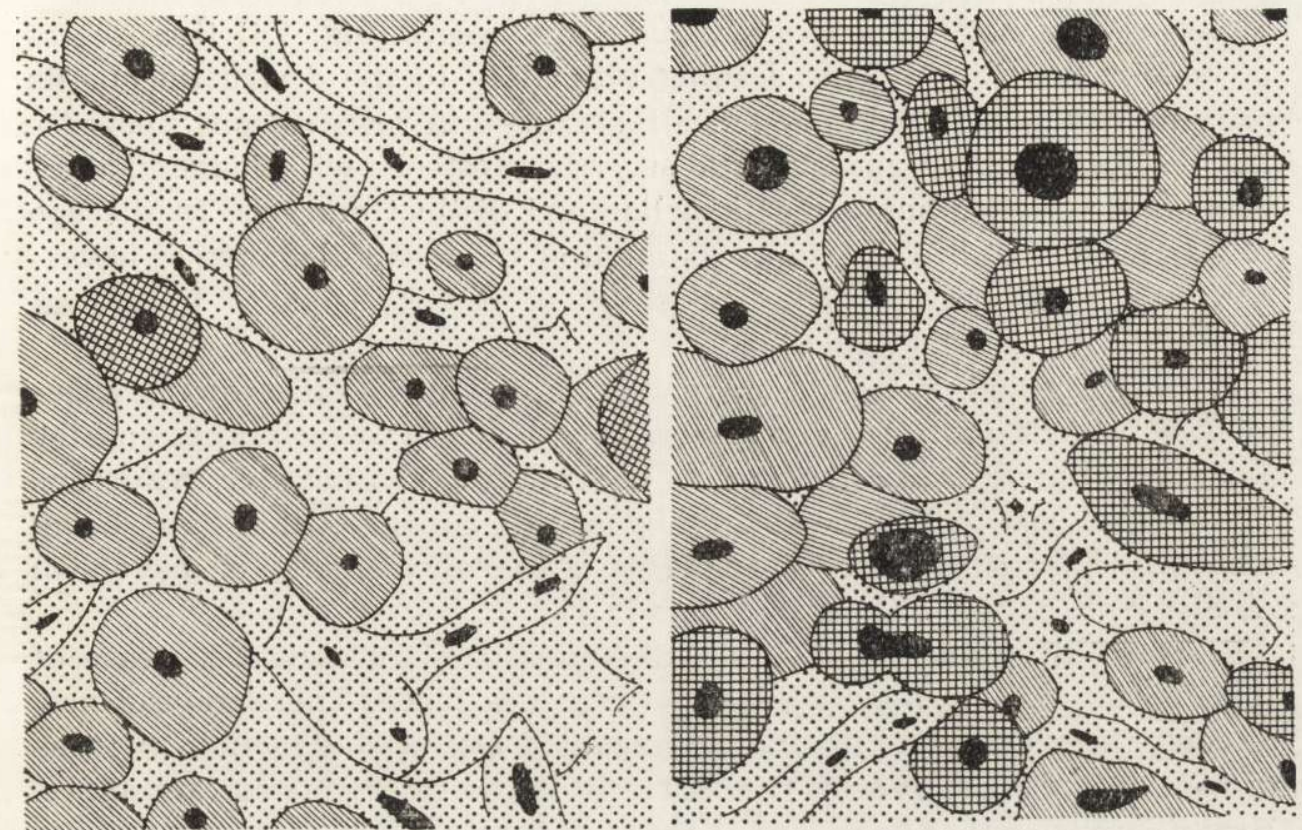

5

6

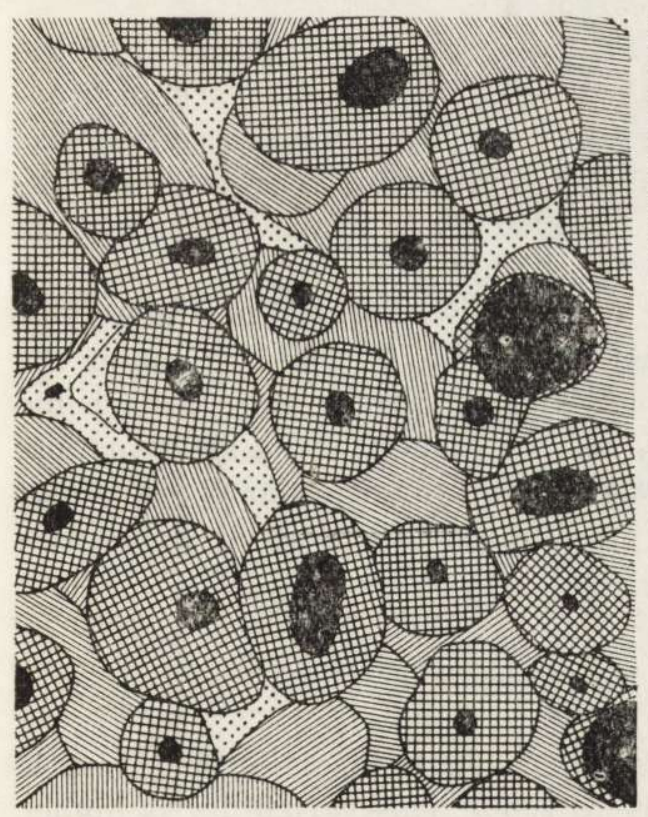

7

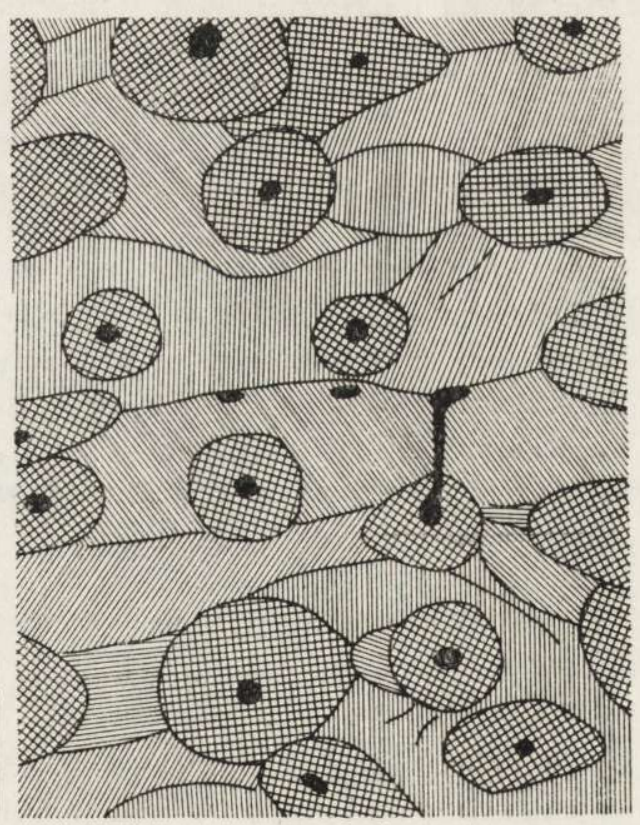

Black fields - sections of haversian canals; dotted fields - primary, not reconstructed bone; hatched fields - reconstruction of the bone in relation to the primary structure; chequered fields - reconstruction of the bone in relation to that in hatched areas. 
4. It seems that in the period from 3 to 7 years (Fig. 1.4) the process of bone remodelling begins, leading ultimately to the destruction of its primary row structure. Among small, arranged in rows osteons undergoing resorption, there appear large secondary osteons with bigger haversian canals, higher number of lamellae and distinct outlines. In the age of 5 to 6 years of life the first maximum of the mean diameter of haversian canals is observed. Also the shape of osteons changes from oval to round.

5. In the period from 7 to 10 years of life (Fig. 1.5) the row arrangement of osteons definitely disappears. They lie close to each other and the amount of intersystemic substance undergoes a considerable reduction. The osteons are built of a large number of lamellae, this fact being responsible for a marked reduction in the mean diameter of haversian canals.

6. Between 10 and 15 years of life (Fig. 1.6-7) a second increase of the intensity of the bone reconstruction takes place. There appear new osteons, the phenomenon being accompanied by the destruction of those previously existing, and by the increase of the intersystemic substance. Newly formed ostens have large haversian canals. Their diameter reaches the second maximum in the 15 th year of life.

7. In the period between 15 and 16 years of life the intensity of the processes of bone reconstruction is reduced. The lamellae are incorporated into large haversian canals, this fact resulting in a renewed decrease of the mean diameter of the channels. The amount of intersystemic substance decreases. This picture shows the analogy to changes occurring in the bone between 7 and 8 years of life.

8. In the period between 18 and 20 years of life (Fig. 1.8) not numerous, small and round osteons occur among large osteons. The amount of the intersystemic substance is appreciable. In some places there are visible small limited foci of the bone reconstruction suggesting its rejuvenation.

In all periods with intensive reconstruction of the bone the most augmented changes were observed in a segment adjoining the bone-marrow cavity.

\section{Results of Measurements}

The variability of diameters of haversian canals in one preparation is considerable and amounts occasionally to $100 \mu$. This variability is higher in periods associated with intensive reconstruction of the bone, hence in the age of 4 to 6 years and 13 to 15 years. In the periods of relative stabilization, e.g. 8 to 10 years, the variability decreases considerably (Fig. 2), and the distribution of values is close to normal. On the other 
hand, an increased scatter is accompanied by assymetric distribution, which manifests as elongation of the arm corresponding to long diameters of haversian canals. For this reason the standard deviation of the arithmetic mean was not calculated since this index of dispersion would not correspond to real distribution of the studied features.
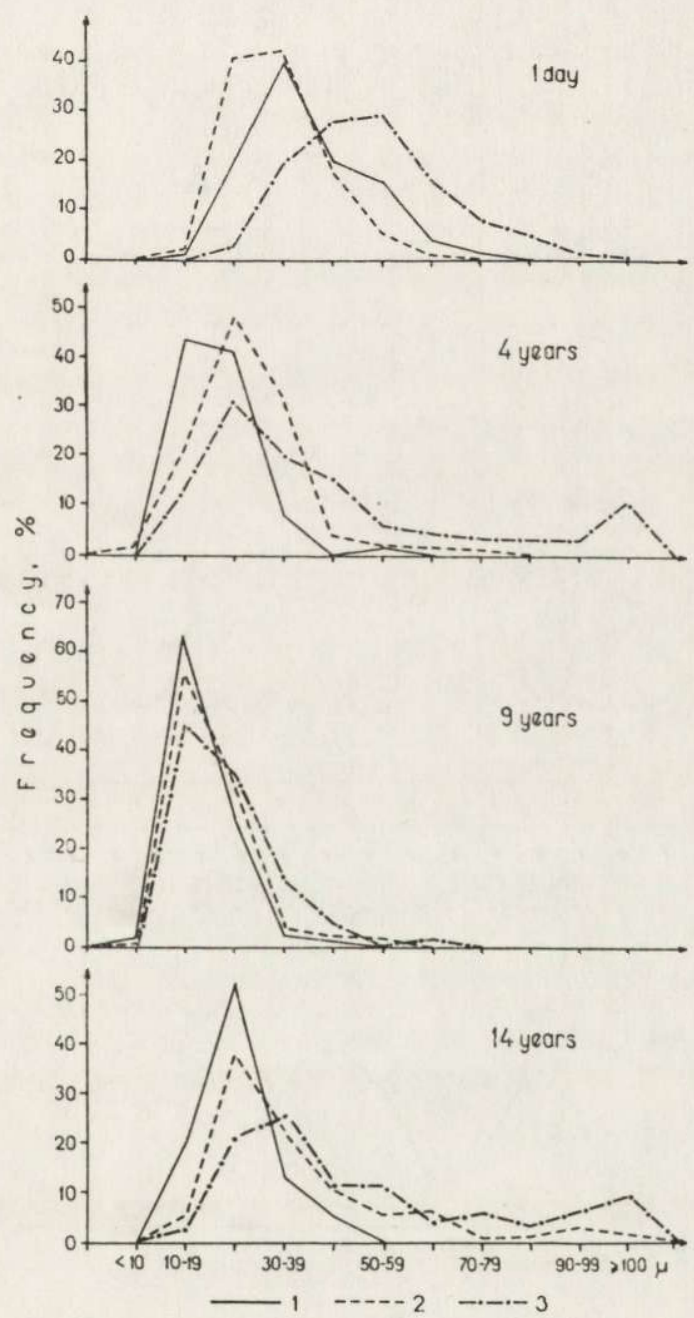

Fig. 2. Frequency distribution of the diameter of haversian canals in individuals of different age.

1 - periosteum adjoining zone, $2-$ central zone, 3 - bone-marrow adjoining zone.

The picture of changes of the mean diameter of haversian canals is shown jointly for all zones in Fig. $3 \mathrm{~A}$ and Table 1. Several phases may be distinguished in the curve depicting changes of this feature. In the 
studied period of ontogenesis from 0 to 20 years two full cycles of changes were observed. They lasted 9 years each and were fairly similar. The phase of increase of the mean channel diameter in the first cycle includes the period from birth to approximately 5 years of age. Subsequently, a reduction of the mean diameter occurs up to approximately 9 years.
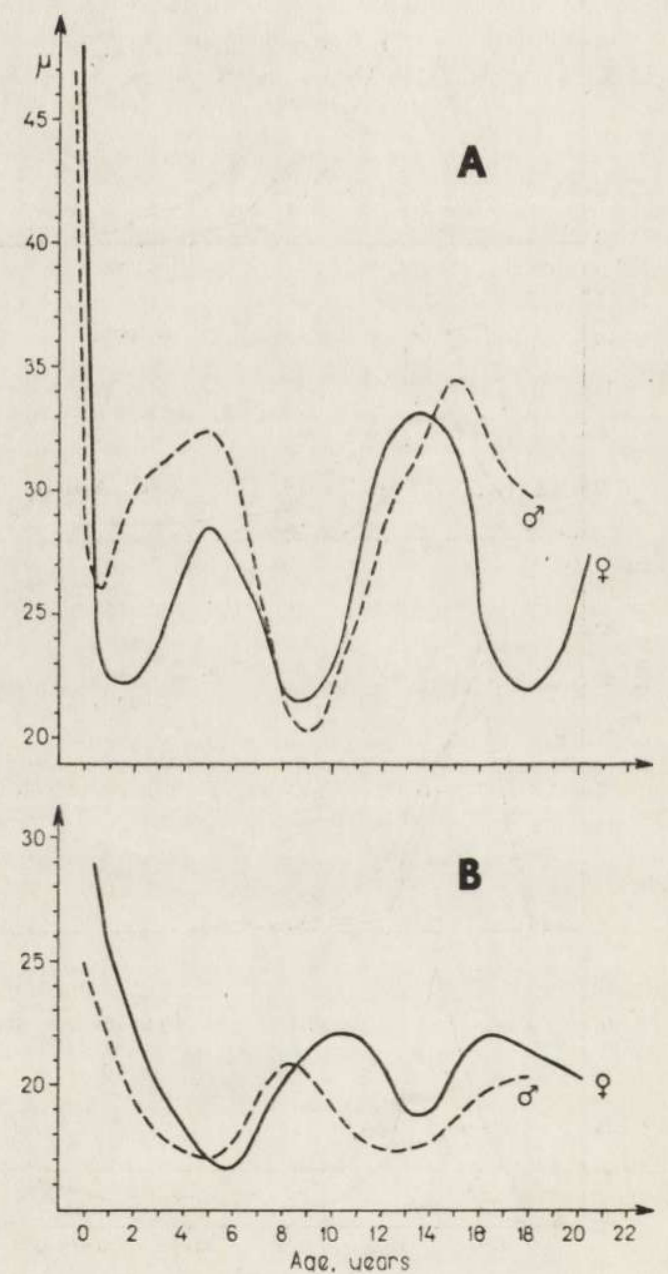

Fig. 3. Changes with age in the mean diameter of haversian canals $(A)$ and their mean number per $1 \mathrm{~mm}^{2}(B)-$ smoothed curves.

The maximum values appear in the years 4,5 and 6 , minimum in 8,9 and 10 years. In order to establish whether these changes are statistically significant Fisher's test for small samples was applied. A zero hypothesis was put forward, that the arithmetic means of haversian canals in the 
age group of 4,5 and 6 years show no differences with the arithmetic means in the group of 8,9 and 10 years. The result of the test $(F=29.4$ at $\nu_{1}=1, \nu_{2}=4>F_{\alpha=0.01}=21.20$ ) denies the zero hypothesis and indicates that the change of the mean channel diameter in the investigated age is statistically highly significant. A similar analysis was carried out by comparing the age group of 8,10 years with the group of 13,14 and 15 years, when the second maximum of the mean diameters of haversian

Table 1

The mean diameter of haversian canals $(A)$ and their number for $1 \mathrm{~mm}^{2}(B)$ (zones $a, b$ and $c$ jointly)

\begin{tabular}{|c|c|c|c|c|c|}
\hline \multirow{2}{*}{\multicolumn{2}{|c|}{ Age }} & \multicolumn{2}{|c|}{$0^{7} \sigma^{7}$} & \multicolumn{2}{|c|}{ 우우 } \\
\hline & & $A, \mu$ & $B$ & $A, \mu$ & $B$ \\
\hline & 46.09 & - & - & - \\
\hline & $\begin{array}{c}36.57 \\
-\end{array}$ & $\overline{-}$ & 51.02 & - \\
\hline & $\begin{array}{l}\text { lays } \\
\text { month }\end{array}$ & $2 \overline{22.86}$ & $2 \overline{3}$ & 28.63 & I \\
\hline 5 & months & - & - & 22.09 & 29.74 \\
\hline & rear & 30.19 & 19.19 & - & - \\
\hline & years & 29.82 & 20.06 & 21.68 & 21.64 \\
\hline 3 & , & 30.51 & 18.67 & 23.08 & 21.14 \\
\hline 4 & " & 33.72 & 18.42 & - & - \\
\hline 5 & ", & 28.67 & 17.98 & - & - \\
\hline 6 & $"$ & 34.36 & 16.53 & 29.65 & 15.94 \\
\hline 7 & ", & 25.23 & 20.58 & 26.23 & 19.74 \\
\hline 8 & , & 22.46 & 20.05 & 21.64 & 20.66 \\
\hline 9 & " & 19.85 & 20.66 & 21.62 & 17.80 \\
\hline 10 & ," & 24.51 & 19.67 & - & - \\
\hline 11 & , & 26.21 & 16.62 & 23.94 & 25.04 \\
\hline 12 & " & 26.58 & 18.92 & 36.60 & 20.73 \\
\hline 13 & , & 27.64 & 15.74 & - & - \\
\hline 14 & , & 38.63 & 18.60 & - & - \\
\hline 15 & " & 34.26 & 18.63 & 32.09 & 20.18 \\
\hline 16 & $"$ & - & - & 24.48 & 23.93 \\
\hline 17 & , & 30.76 & 20.04 & 20.47 & 21.63 \\
\hline 18 & " & 30.51 & 20.45 & 22.55 & 19.88 \\
\hline 20 & ", & - & - & 29.36 & 21.49 \\
\hline
\end{tabular}

canals occurs. The results of the test $\left(F=12.1\right.$ at $\nu_{1}=1$ and $\nu_{2}=4>$ $>F=0.05=7.71$ ) also indicates statistical significance of changes in this period of ontogenesis.

The examination of significance of differences was applied for males only, since in the case of females the data were not available for each year of life, this fact making statistical analysis difficult. However, the similarity of the curves in both sexes justifies the generalization of results.

In the analysis of age-related changes of the mean diameter of haversian canals the existence of sexual dimorphism is not clear. It seems that 
females have slightly smaller channel diameters than males. Perhaps some shift of the cycles in time also occurs.

The differences in the mean diameter of haversian canals in three zones of the bone section were observed. The smallest diameter occurs in the periosteum adjoining zone, and the largest in the zone adjoining to bone-marrow (Table 2). Also the age-associated changes of the mean number of haversian canals per $1 \mathrm{~mm}^{2}$ show cyclic character and are similar in both sexes and in 3 discussed zones (Tables 1 and 3).

Table 2

The mean diameter of haversian canals in three zones of the bone section, $a$ - periosteum adjoining zone, $b$ - central zone, $c$ - bone-marrow adjoining zone.

\begin{tabular}{|c|c|c|c|c|c|c|c|}
\hline \multirow{2}{*}{\multicolumn{2}{|c|}{ Age }} & \multicolumn{3}{|c|}{$0^{x} 0^{x}$} & \multicolumn{3}{|c|}{ 우 우 } \\
\hline & & $a$ & $b$ & $c$ & $a$ & $b$ & $c$ \\
\hline \multicolumn{2}{|c|}{ Foetus } & 44.69 & 41.14 & 52.44 & - & - & - \\
\hline \multicolumn{2}{|c|}{1 day } & 38.99 & 33.79 & 36.94 & 48.24 & 50.19 & 54.64 \\
\hline & days & - & - & - & 40.14 & 21.08 & 24.74 \\
\hline \multicolumn{2}{|c|}{1 month } & 28.09 & 17.31 & 23.19 & - & - & - \\
\hline \multirow{2}{*}{\multicolumn{2}{|c|}{$\begin{array}{l}5 \text { months } \\
1 \text { year }\end{array}$}} & - & - & $\overline{-10}$ & 28.64 & 19.63 & 17.99 \\
\hline & & 17.03 & 33.74 & 39.79 & $-\pi$ & - & \\
\hline \multicolumn{2}{|c|}{2 years } & 22.09 & 27.99 & 41.39 & 15.17 & 16.47 & 33.41 \\
\hline 3 & ," & 19.59 & 24.00 & 47.95 & 20.38 & 25.79 & 23.09 \\
\hline 4 & , & 20.99 & 27.44 & 52.79 & - & - & - \\
\hline 5 & " & 24.34 & 25.84 & 35.82 & - & - & - \\
\hline 6 & , & 25.04 & 40.25 & 37.88 & 22.94 & 27.79 & 38.21 \\
\hline 7 & $"$ & 23.24 & 22.91 & 29.54 & 22.73 & 21.56 & 34.40 \\
\hline 8 & , & 19.18 & 23.47 & 24.73 & 17.13 & 21.14 & 26.64 \\
\hline 9 & ", & 18.07 & 19.41 & 22.07 & 18.23 & 22.63 & 23.99 \\
\hline 10 & , & 18.85 & 26.79 & 27.89 & - & - & \\
\hline 11 & , & 22.34 & 24.29 & 32.09 & 18.64 & 20.89 & 32.29 \\
\hline 12 & , & 18.57 & 25.03 & 36.16 & 27.34 & 33.59 & 48.87 \\
\hline 13 & , & 23.09 & 25.89 & 34.07 & - & - & - \\
\hline 14 & , & 24.49 & 38.91 & 52.30 & - & - & \\
\hline 15 & " & 26.49 & 33.59 & 42.69 & 25.24 & 32.16 & 38.87 \\
\hline 16 & , & - & - & - & 20.71 & 24.17 & 28.57 \\
\hline 17 & " & 22.59 & 27.79 & 41.94 & 18.37 & 19.49 & 23.53 \\
\hline 18 & " & 25.44 & 27.99 & 38.09 & 20.44 & 22.34 & 24.89 \\
\hline 20 & , & - & - & - & 32.13 & 28.79 & 36.17 \\
\hline
\end{tabular}

The changes with age in the index of the area of haversian canals and the total area of all zones are depicted in Fig. 4. In the foetal period and in newborns this index is high. The area of haversian canals occupies in foetuses approximately $20 \%$ of the bone section area. Up to the age of 1 year this index decreases and then remains on a relatively constant level and varies from 1.5 to $4.5 \%$, with the mean $2.8 \%$. No clear differences between sexes and between 3 zones of the bone section were observed in this respect (Table 4). 
Table 3

The mean number of haversian canals for $1 \mathrm{~mm}^{2}$ in 3 zones of the bone section (designations as in Table 2).

\begin{tabular}{|c|c|c|c|c|c|c|c|}
\hline \multirow{2}{*}{\multicolumn{2}{|c|}{ Age }} & \multicolumn{3}{|c|}{$\sigma^{x} \sigma^{x}$} & \multicolumn{3}{|c|}{ q 9} \\
\hline & & $a$ & $b$ & $c$ & $a$ & $b$ & $c$ \\
\hline \multicolumn{2}{|c|}{ Foetus } & - & - & - & - & - & - \\
\hline & - & - & - & - & - & - \\
\hline \multicolumn{2}{|c|}{$\begin{array}{l}1 \text { day } \\
8 \text { days }\end{array}$} & - & - & - & - & - & - \\
\hline \multicolumn{2}{|c|}{1 month } & 25.70 & 22.98 & 36.34 & - & - & - \\
\hline \multicolumn{2}{|c|}{5 months } & - & - & - & 28.49 & 29.42 & 31.30 \\
\hline \multicolumn{2}{|c|}{1 year } & 21.40 & 19.06 & 17.11 & - & - & - \\
\hline \multicolumn{2}{|c|}{2 years } & 19.68 & 22.31 & 18.20 & 18.16 & 28.32 & 18.43 \\
\hline \multicolumn{2}{|c|}{$3 \quad$} & 19.89 & 21.53 & 14.58 & 18.60 & 21.19 & 23.63 \\
\hline \multicolumn{2}{|c|}{$4 \quad "$} & 21.50 & 18.66 & 15.10 & - & - & - \\
\hline \multicolumn{2}{|c|}{$5 \quad "$} & 19.04 & 18.88 & 16.01 & - & - & - \\
\hline \multicolumn{2}{|c|}{$6 \quad$} & 20.67 & 14.13 & 14.78 & 17.83 & 16.70 & 13.28 \\
\hline \multicolumn{2}{|c|}{$7 \quad$} & 25.66 & 20.97 & 15.12 & 20.70 & 19.25 & 17.26 \\
\hline \multicolumn{2}{|c|}{$8 \quad$} & 21.51 & 19.21 & 19.44 & 23.44 & 19.34 & 19.10 \\
\hline \multicolumn{2}{|c|}{$9 \quad "$} & 22.05 & 20.21 & 19.72 & 22.06 & 15.09 & 16.24 \\
\hline \multicolumn{2}{|c|}{$10 \quad "$} & 24.48 & 18.84 & 15.68 & - & - & - \\
\hline \multicolumn{2}{|c|}{$11 "$} & 21.64 & 14.83 & 13.46 & 24.14 & 26.01 & 24.97 \\
\hline \multicolumn{2}{|c|}{12} & 20.23 & 17.71 & 18.83 & 25.70 & 21.40 & 15.09 \\
\hline & 15.21 & 18.03 & 13.99 & - & - & - \\
\hline \multicolumn{2}{|c|}{$14 \quad "$} & 19.95 & 18.60 & 17.26 & - & - & - \\
\hline \multicolumn{2}{|c|}{$15 \quad "$} & 21.10 & 17.44 & 17.34 & 20.84 & 21.38 & 18.32 \\
\hline \multicolumn{2}{|c|}{$16 \quad "$} & - & - & - & 26.62 & 23.22 & 21.94 \\
\hline \multirow{3}{*}{$\begin{array}{l}17 \\
18 \\
20\end{array}$} & ", & 22.85 & 22.05 & 16.34 & 22.35 & 22.17 & 20.36 \\
\hline & " & 24.22 & 20.48 & 16.65 & 22.23 & 19.19 & 18.22 \\
\hline & $"$ & - & - & - & 22.15 & 21.86 & 20.47 \\
\hline
\end{tabular}

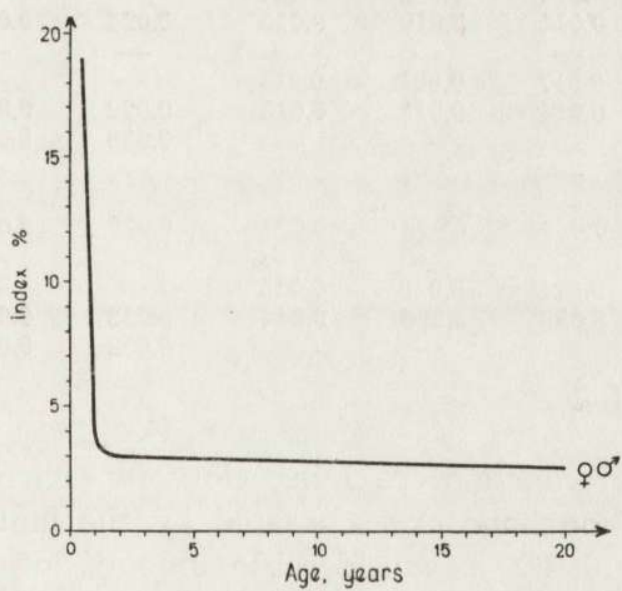

Fig. 4. Changes with age in the index of haversian canals area to the total area of bone section (smoothed curve). 


\section{DISCUSSION}

The described investigations demonstrated that in ontogenesis of the European bison the development and reconstruction of the bone occurs in a cyclical manner. The increased resorption of old structures and the occurrence of new osteons take place for the first time in the age of 4 to 6 years, and then again at 12 to 15 years. This cyclic occurence is reflected in age-dependent changes of the two principal features describing the structure of the studied bone. A rectilinear reciprocal relationship between the size and number of channels could be only ex-

Table 4

Indices of the area of haversian canals to the total area of the bone section (designations as in Table 2).

\begin{tabular}{|c|c|c|c|c|c|c|c|c|c|}
\hline \multirow{2}{*}{\multicolumn{2}{|c|}{ Age }} & \multicolumn{4}{|c|}{$0^{x} 0^{x}$} & \multicolumn{4}{|c|}{ 우 우 } \\
\hline & & $a$ & $b$ & $c$ & $\bar{x}_{a b c}$ & $a$ & $b$ & $c$ & $\bar{x}_{a b c}$ \\
\hline \multicolumn{2}{|c|}{ Foetus } & 0.201 & - & 0.219 & 0.210 & - & - & - & - \\
\hline \multirow{2}{*}{\multicolumn{2}{|c|}{$\begin{array}{l}1 \text { day } \\
8 \text { days }\end{array}$}} & 0.083 & - & 0.120 & 0.101 & 0.203 & - & 0.112 & 0.157 \\
\hline & & - & - & - & - & - & - & - & - \\
\hline & month & 0.080 & 0.038 & 0.050 & 0.056 & $0 . \overline{032}$ & $0 . \overline{032}$ & $0 . \overline{029}$ & $\overline{0.31}$ \\
\hline & $\begin{array}{l}\text { months } \\
\text { year }\end{array}$ & $0 . \overline{040}$ & $0 . \overline{029}$ & $0 . \overline{048}$ & $0 . \overline{039}$ & $\frac{0.032}{-}$ & $\begin{array}{c}0.032 \\
-\end{array}$ & $\begin{array}{r}0.029 \\
\end{array}$ & $\begin{array}{l}0.031 \\
-\end{array}$ \\
\hline & years & 0.023 & 0.026 & 0.033 & 0.027 & - & - & - & - \\
\hline 3 &, & 0.020 & 0.037 & 0.024 & 0.027 & 0.018 & 0.023 & 0.030 & 0.024 \\
\hline 4 & " & 0.025 & 0.030 & 0.032 & 0.027 & - & - & - & - \\
\hline 5 & $"$ & $\overline{01}$ & $\overline{0}$ & $\overline{030}$ & $\overline{025}$ & $\overline{07}$ & $\overline{076}$ & $\overline{0}$ & $\dot{\overline{130}}$ \\
\hline 6 & " & 0.031 & 0.016 & $\begin{array}{l}0.039 \\
0\end{array}$ & 0.025 & 0.025 & 0.026 & 0.039 & 0.030 \\
\hline $\begin{array}{l}7 \\
8\end{array}$ & $"$ & $\begin{array}{l}0.018 \\
0.011\end{array}$ & $\begin{array}{l}0.016 \\
0.014\end{array}$ & $\begin{array}{l}0.028 \\
0.019\end{array}$ & $\begin{array}{l}0.021 \\
0.015\end{array}$ & $0 . \overline{022}$ & $0 . \overline{014}$ & $0 . \overline{026}$ & $0 . \overline{021}$ \\
\hline 9 & ", & - & - & - & - & - & - & - & - \\
\hline 10 & ", & 0.016 & 0.017 & 0.024 & 0.019 & - & - & - & - \\
\hline 11 & " & 0.021 & 0.014 & 0.011 & 0.015 & 0.022 & 0.036 & 0.060 & 0.039 \\
\hline 12 & " & - & - & - & - & 0.033 & 0.042 & 0.069 & 0.048 \\
\hline 13 & $"$ & - & $\overline{-}$ & $\overline{-}$ & - & - & - & - & - \\
\hline $\begin{array}{l}14 \\
15\end{array}$ & $"$ & $0 . \overline{029}$ & $0 . \overline{030}$ & $0 . \overline{028}$ & $0 . \overline{029}$ & $0 . \overline{025}$ & $0 . \overline{026}$ & $0 . \overline{040}$ & $0 . \overline{030}$ \\
\hline $\begin{array}{l}15 \\
16\end{array}$ & ”, & - & - & - & 0.028 & 0.020 & - & - & 0.00 \\
\hline 17 & $"$ & 0.020 & 0.024 & 0.040 & 0.028 & - & - & - & - \\
\hline 18 & ", & 0.033 & 0.032 & 0.068 & 0.044 & 0.022 & 0.017 & 0.015 & 0.018 \\
\hline 20 & ", & - & - & - & - & 0.032 & 0.034 & 0.045 & 0.037 \\
\hline
\end{tabular}

pected if haversian canals were lying close to each other. In fact the channels in the bison bone are separated by the lammellae of the haversian system and by a considerable amount of the intersystemic substance. It was found that in the periosteous zone no correlation exists between the number of channels and their size (Fig. 5A). On the other hand, in the central and perimedullary zones a trend of inverse 
correlation exists, although it does not show a rectilinear character (Fig. 5B). In the case when a small number of haversian canals, i.e. less than 20 , falls for $1 \mathrm{~mm}^{2}$, their diameter is large and amounts to $32 \mu$ on the average, the dispersion of results being also high: from 15 to $53 \mu$.
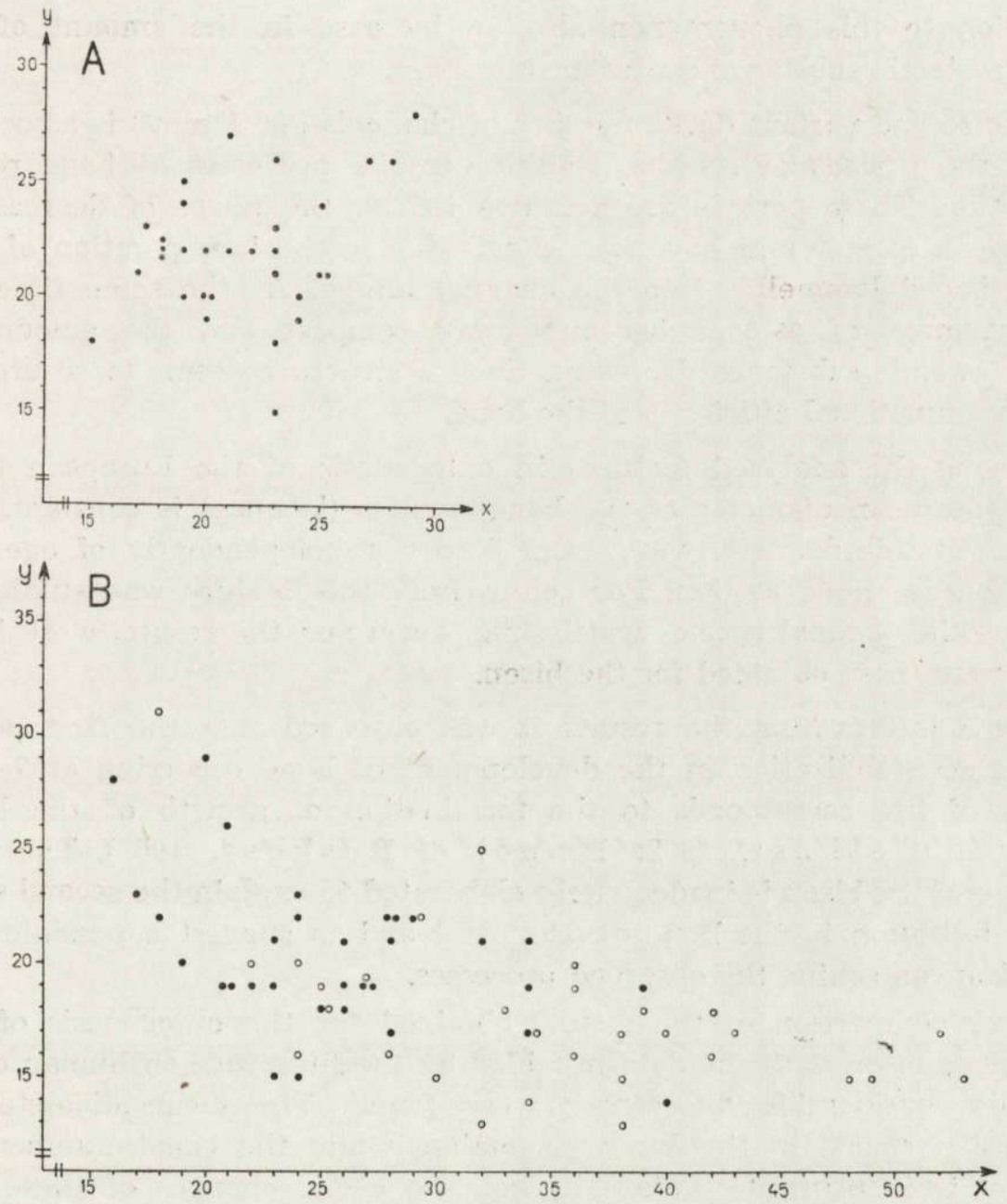

Fig. 5. Scatter diagram of the mean diameter of haversian canals $(X)$ and their mean number for $1 \mathrm{~mm}^{2}(\mathrm{Y})$.

$A$ - periosteum adjoining zone, $B$ - central zone - - and bone-marrow adjoining zone -0 .

When the number of the channels per $1 \mathrm{~mm}^{2}$ is high, i.e. 20 or more, their mean diameter is small $-27.7 \mu$. The dispersion is also smaller and ranges from 16 to $36 \mu$. 
It was observed that the former case is characteristic for the periods of intensive reconstruction of the bone when an abrupt increase of the mean diameter of haversian canals occurs. The rise of the mean diameter results directly from the appearance of new osteons with a large channel lumen, and from the destruction of the old structure of the bone. In relation to this phenomenon also an increase in the amount of the intersystemic substance occurs in this phase.

The second variant (large number of channels per $1 \mathrm{~mm}^{2}$ ) is associated with the periods of relative stability in the processes of bone reconstruction. These periods are accompanied by the phase of decrease of the mean diameter of haversian canals due to the incorporation of new ring-shaped lammellae into the channel lumen. At the same time the arrangement of osteons becomes more compact and the amount of intersystemic substance decreases. Such a structure seems to secure the highest functional efficiency of the bone.

Among the analyzed features in ontogenesis of the European bison only the mean diameter of the bone cavities (lacunae) is constant. The values of this diameter vary from 5 to $6 \mu$ independently of age, sex and zone of bone section. For comparison, this feature was studied in a few other animal species (cattle, pig, boar) and the results were identical with those obtained for the bison.

When interpreting the results it was observed that the first period of higher stabilization in the development of bone occurring at 7 to 8 years of life corresponds to the termination of growth of the bison skeleton (Roskosz, 1962; Empel \& Roskosz, 1963). The physiology of the bison is inadequately elaborated to explain the second stage of stabilization in the bone development and to suggest a possible mechanism controlling the observed processes.

After comparison of the results obtained for the ontogenesis of the European bison with the data provided by the literature on human ontogenesis considerable differences were found. The mean diameter of haversian canals in the bison is smaller while the canal number for $1 \mathrm{~mm}^{2}$ is in principle higher. In man no cyclic changes of these two parameters in relation to age were observed. The mean diameter of haversian canals in man increases continuously with age, while the number of channels decreases. The studies of the man were not carried out in one year intervals and were based on groups of rather large age span. Hence it is difficult to answer unequivocally whether the unidirectional trend of changes of the studied parameters in man represents a real picture, or whether it is only the resultant of unknown particular changes. 


\section{REFERENCES}

1. Be umer P., 1914: Die Unterscheindung von Menschen- und Tierknochen in forensischer Beziehung. (after Lochte: Gerichtsärztl. und Polizeiärztl. Wiesbaden).

2. Empel W. \& Roskosz T., 1963: Das Skelett der Gliedmassen des Wisents, Bison bonasus (Linnae u s, 1758). Acta theriol., 7, 13: 259-300.

3. Giese E., 1909: Über die Diagnose der Herkunft von Knochenfragmenten in forensischer Beziehung durch vergleichende histologische Untersuchungen. Vjrschr. f. ger. Med., 38, 28.

4. Grass E., 1909: Untersuchungen zur Frage der Differentialdiagnose zwischen Menschen- und Tierknochen. Inaug. Diss. Berlin.

5. Kos sakowski A., 1964: Mikroskope różnicowanie przynależności gatunkowej kości. Msc.

6. La croix P., 1951: The organisation of bone. Churchil: 1-235. London.

7. M u e lle r B., 1953: Gerichtlische Medizin. Springer Verlag: 1-1080. Berlin.

8. $\mathrm{Rämsch}$ R. \& Z e rndt B., 1963: Vergleichende Untersuchungen der Haversschen Kanäle zwischen Menschen und Haustieren. Archiv f. Kriminologie. 3, 4: 74 .

9. Roskosz T., 1962: Morfologie der Wirbelsäule des Wisents, Bison bonasus (Li n n a e u s, 1758). Acta theriol., 6, 5: 113-164.

10. Schranz D., 1933: Der Oberarmknochen und seine gerichtsmedizinische Bedeutung aus dem Gesichtpunkt der Identität. Zschr. f. ger. Med. 22: 352-363.

11. Sim on in C., 1955: Médicine légale judiciaire. Libraire Maloine: 1-1054. Paris.

12. Thompson R. C. \& Ballou I. E., 1956: Studies of metabolic. J. Biol. Chem. 223: 795-810.

13. W a d a T., 1909: Über die Unterscheidung der Mensche und Tierknochen. Vjschr. f. gen. Med. 37: 265-272.

Accepted, December 20, 1971

State Museum of Archaeology, Warszawa, Dluga 52.

\section{Alicja LASOTA i Andrzej KOSSAKOWSKI}

\section{BUDOWA MIKROSKOPOWA KOSCI W ONTOGENEZIE ŻUBRA}

\section{Streszczenie}

Celem pracy jest zbadanie przemian zachodzących $\mathrm{w}$ strukturze mikroskopowej kości w przebiegu ontogenezy żubra. Materiał obejmuje 20 samców i 16 samic w wieku od płodowego do 20 lat.

Analizę przeprowadzono na podstawie szlifów kostnych wykonywanych z trzonu kości piszczelowej. Oprócz opisu morfologicznego wykonywano następujące pomiary: średnica kanałów Haversa, liczba kanałów Haversa na $1 \mathrm{~mm}^{2}$, mniejsza średnica 
jamek kostnych oraz liczono wskaźnik powierzchni kanałów Haversa do powierzchni całkowitej przekroju kostnego.

Na podstawie uzyskanych wyników w ontogenezie żubra wyróżniono 8 okresów różniących się między sobą fazą przebudowy struktury kostnej (Fig. 1).

Stwierdzono, że większość badanych cech pomiarowych podlega znacznym zmianom $\mathrm{z}$ wiekiem. Srednia średnica kanałów Haversa zmienia się w sposób cykliczny (Fig. 3). W ciągu 20 lat życia u żubra występują dwa cykle zmian. Każdy trwa około 9 lat i składa się z fazy wzrastania i zmniejszania się średniej średnicy. Faza zwiększania średniej średnicy związana jest $\mathrm{z}$ okresami intensywnej przebudowy kości. Towarzyszy jej zmniejszenie liczby kanałów Haversa na $1 \mathrm{~mm}^{2}$ oraz zwiększanie substancji międzysystemowej. Faza zmniejszania średniej średnicy wiąże się z okresami większej stabilizacji w procesach przebudowy kości. Wzrasta wtedy liczba kanałów Haversa na $1 \mathrm{~mm}^{2}$.

Wskaźnik powierzchni kanałów Haversa do powierzchni całkowitej przekroju ulega gwaltownemu zmniejszaniu w pierwszym roku życia, następnie aż do 20 lat utrzymuje się na dość wyrównanym poziomie (Fig. 4). Jedną cechą stałą w ontogenezie żubra jest średnica jamek kostnych. W podsumowaniu autorzy stwierdzają, że procesy przebudowy kości u żubra trwają przez cały badany wycinek ontogenezy, od urodzenia do 20 lat. Intensywność tych procesów jest zmienna, występuje jednak stały rytm zmian. 